\title{
Perencanaan Instalasi Pengolahan Air Limbah (IPAL) Industri Agar-agar
}

\author{
Adelia Puspita Sari dan Adhi Yuniarto* \\ Jurusan Teknik Lingkungan, Fakultas Teknik Sipil dan Perencanaan, Institut Teknologi Sepuluh \\ Nopember (ITS) \\ Jl. Arief Rahman Hakim, Surabaya 60111 Indonesia \\ *e-mail: adhy@its.ac.id
}

\begin{abstract}
Abstrak - Industri agar-agar merupakan salah satu industri pangan yang menghasilkan limbah cair dalam jumlah besar terutama dari proses pencucian bahan baku. Berdasarkan PerGub Jatim no. 72 tahun 2013 terdapat 6 parameter baku mutu air limbah yang harus dipenuhi sebelum membuang limbah ke badan air. Parameternya adalah BOD, COD, TSS, pH, ammonia dan sisa klor. Pada perencanaan ini digunakan data primer yang berasal dari industri agar-agar $X$ yang berlokasi di Kab. Malang yang diambil dengan menggunakan metode Integrated Sampling. Data acuan perencanaan berasal dari outlet 1 dan 2 yang tidak memenuhi ambang baku mutu dengan nilai BOD sebesar $514,4 \mathrm{mg} / \mathrm{l}$, COD sebesar $1710,59 \mathrm{mg} / \mathrm{l}$, dan TSS sebesar 269,26 mg/l. Sedangkan untuk parameter pencemar lainnya sudah memenuhi baku mutu. Unit IPAL yang direncanakan merupakan unit-unit pengolahan fisik-kimia yang terdiri dari bar screen, bak ekualisasi, prasedimentasi, koagulasiflokulasi, sedimentasi dan filter dengan media zeolite. Perhitungan BOQ dan RAB menggunakan HSPK Kota Malang 2015 dan didapatkan angka sebesar Rp141.665.444,00 untuk pembangunan seluruh unit IPAL.
\end{abstract}

Kata Kunci- Desain IPAL, industri agar-agar, pengolahan fisik-kimia, perencanaan IPAL, rumput laut.

\section{PENDAHULUAN}

$S_{\mathrm{d}}^{\mathrm{E}}$ EKTOR Industri merupakan sektor yang seringkali dijadikan acuan tolak ukur kemajuan suatu negara. Salah satu industri yang sedang pesat perkembangannya adalah industri pengolahan rumput laut. Industri rumput laut merupakan suatu industri yang memproses bahan baku rumput laut menjadi suatu makanan atau minuman, dan juga menghasilkan limbah yang disebabkan pencucian rumput laut karena dicuci dengan menggunakan air dan bahan-bahan kimia seperti $\mathrm{NaOH}, \mathrm{H}_{2} \mathrm{O}_{2}$, $\mathrm{KOH}, \mathrm{KCl}$. (Sedayu et.al, 2007) ${ }^{[4]}$

Berdasarkan UU RI No.32 Tahun 2009 Tentang Perlindungan dan Pengelolaan Lingkungan Hidup ${ }^{[6]}$, maka setiap industri maupun instansi/ badan usaha harus bertanggung jawab terhadap pengelolaan limbah yang dihasilkan dari kegiatannya. Pengelolaan limbah dapat dilakukan dengan membangun suatu IPAL (Instalasi Pengolahan Air Limbah) yang efektif dengan menyesuaikan pada karakteristik limbah dan beban pencemar. Oleh karena itu akan dilakukan perencanaan desain IPAL untuk industri agar-agar yang sesuai dengan kriteria desain dengan tidak mengabaikan karakteristik limbah dan beban pencemar yang terdapat pada air limbah. Perencanaan melingkupi observasi lapangan terkait karakteristik dan pola timbulan air limbah, hingga perhitungan
Detail Engineering Design (DED) serta Bill of Quantity (BOQ) dan Rencana Anggaran Biaya (RAB) dari masingmasing unit IPAL yang digunakan.

\section{METODE PERENCANAAN}

\section{A. Pengumpulan Data}

Pengumpulan data dilakukan untuk mengumpulkan data yang diperlukan dalam perencanaan. Terdapat 2 sumber data yang digunakan yakni data primer dan data sekunder. Datadata yang diperlukan meliputi :

1) Data Primer

- Pengukuran karakteristik limbah cair yang dilakukan dengan metode pengambilan sampel yakni metode Integrated Sample di 3 outlet yang berbeda.

- Perhitungan luas lahan dengan menggunakan roll meter.

2) Data Sekunder

- Gambaran umum perusahaan yang didapat dari profil perusahaan

- Debit harian pada jam normal dan jam puncak

- Baku mutu air limbah untuk kegiatan/usaha pengolahan rumput laut yang didapat dari PerGub Jatim no. 72 Tahun 2013[3]

- Harga Satuan Pokok Kerja (HSPK) Kota Malang tahun 2015[2]

\section{B. Pengolahan dan Analisis Data}

Pengolahan data meliputi perhitungan debit, penetapan baku mutu effluent air limbah yang disesuaikan dengan PerGub Jatim No. 72 tahun $2013^{[3]}$, perhitungan dimensi unit IPAL, penggambaran DED (Detail Engineering Design) menggunakan software AutoCAD, perhitungan BOQ (Bill of Quantity) dan RAB (Rencana Anggaran Biaya) untuk unit IPAL.

\section{Hasil dan Pembahasan}

Dari data yang telah dianalisis akan dilakukan pembahasan dari masing-masing unit terkait dengan kriteria desain, perhitungan dimensi, profil hidrolis semua unit hingga perhitungan BOQ dan RAB untuk semua unit IPAL. Pembahasan dilakukan untuk mengetahui kesesuaian kriteria desain dengan perencanaan dimensi unit-unit IPAL.

\section{Kesimpulan dan Saran}

Kesimpulan didapatkan dari hasil pembahasan yang menjawab tujuan perencanaan. Sedangkan saran berisi hal-hal 
yang masih dapat dikerjakan dengan lebih baik dan dapat dikembangkan lebih lanjut.

\section{PEMBAHASAN}

\section{A. Gambaran Umum IPAL Eksisting}

Kondisi eksisting IPAL di Industri X, Kab. Malang yang merupakan tempat pengambilan sampel hanya mengolah 2 outlet saja yang mengalir menuju IPAL eksisting. Yakni outlet 2 dan 3. Outlet pertama bersumber dari proses pra-ekstraksi alkali dan pencucian tahap 1 dan 2. Outlet yang kedua bersumber dari proses produksi lanjutan pencucian tahap lanjutan sedangkan outlet ketiga bersumber dari proses pencucian lanjutan hingga pemasakan. Oleh karena itu akan dilakukan perencanaan ulang desain IPAL yang sesuai untuk ketiga outlet.

\section{B. Penentuan Kualitas Limbah Industri Agar-agar}

Pada perencanaan kali ini penentuan kualitas air limbah dilakukan pada sampel yang berasal dari outlet 1, 2 dan 3 . Pengujian kualitas sampel dilakukan di laboratorium lingkungan Perum Jasa Tirta I Malang. Pada Tabel-tabel berikut merupakan data karakteristik masing-masing outlet pada Industri Agar-agar X:

Tabel 1.

Karakteristik Limbah Outlet 1 Industri Agar-agar X

\begin{tabular}{|c|c|c|c|c|}
\hline No & Parameter & Satuan & Hasil & Metode Analisa \\
\hline 1 & $\mathrm{pH}$ & - & 7 & Elektrometri \\
\hline 2 & BOD & $\mathrm{mg} / \mathrm{l}$ & 877.7 & APHA. 5210 B-1998 \\
\hline 3 & COD & $\mathrm{mg} / \mathrm{l}$ & 3029 & Spektrofotometri \\
\hline 4 & TSS & $\mathrm{mg} / \mathrm{l}$ & 282 & APHA. 2540 D-2005 \\
\hline 5 & $\begin{array}{l}\text { Ammonia* } \\
(\mathrm{NH} 3 \mathrm{~N})\end{array}$ & $\mathrm{mg} / \mathrm{l}$ & 2.9 & APHA. 4500-NH3 F-2005 \\
\hline 6 & Klorin bebas* & $\mathrm{mg} / \mathrm{l}$ & $<0.011$ & QI/LKA/50 \\
\hline 7 & Salinitas & ppt & 4.4 & Salinometer \\
\hline
\end{tabular}

Tabel 2.

Karakteristik Limbah Outlet 2 Industri Agar-agar X

\begin{tabular}{ccccc}
\hline \hline No & Parameter & Satuan & Hasil & Metode Analisa \\
\hline 1 & $\mathrm{pH}$ & - & 9.9 & Elektrometri \\
2 & $\mathrm{BOD}$ & $\mathrm{mg} / \mathrm{l}$ & 324.1 & APHA. 5210 B-1998 \\
3 & $\mathrm{COD}$ & $\mathrm{mg} / 1$ & 1020 & Spektrofotometri \\
4 & TSS & $\mathrm{mg} / \mathrm{l}$ & 262.6 & APHA. 2540 D-2005 \\
5 & Ammonia* & $\mathrm{mg} / 1$ & 3.95 & APHA. 4500-NH3 F- \\
5 & (NH3N) & & & 2005 \\
6 & Klorin bebas* & $\mathrm{mg} / 1$ & 0.2 & QI/LKA/50 \\
7 & Salinitas & $\mathrm{ppt}$ & 1 & Salinometer \\
\hline \hline
\end{tabular}

* : hasil sudah memenuhi baku mutu

(sumber : Lab. Lingkungan PJT I, 2016)

Dari hasil uji laboratorium di atas, dapat dilihat bahwa parameter yang belum memenuhi baku mutu hanyalah BOD, COD dan TSS. Sedangkan untuk salinitas, tidak tercantum pada baku mutu yang digunakan menurut Pergub Jatim no. 72 tahun $2013^{[3]}$. Untuk hasil uji laboratorium pada outlet 3 , seluruh parameter sudah memenuhi baku mutu.

Dengan berdasarkan pada hasil analisis itulah, untuk perencanaan IPAL kali ini akan merancang IPAL yang sesuai untuk air limbah yang bersumber dari outlet 1 dan 2, sedangkan air limbah yang bersumber dari outlet 3 akan dipisahkan pengolahannya menggunakan pengolahan air bersih untuk menurunkan kadar salinitasnya saja. Untuk unit pengolahan air bersih, tidak akan dijelaskan karena dianggap tidak sesuai dengan ruang lingkup perencanaan.

\section{Penentuan Debit Limbah Industri Agar-agar}

Penentuan debit air limbah pada Tugas Akhir kali ini, dilakukan dengan pengambilan data sekunder. Data sekunder yang digunakan merupakan hasil uji milik perusahaan $\mathrm{X}$ pada inlet 1 dan 2. Didapat debit puncak per hari sebesar $192 \mathrm{~m}^{3}$.

\section{Perhitungan Detail Engineering Desain}

Perhitungan yang dilakukan meliputi perhitungan unit bangunan pre-treatment yaitu bar screen, bak ekualisasi, dan prasedimentasi, hingga unit bangunan pengolahan utama. Perhitungan bersumberkan dari berbagai literatur dengan mengacu pada SNI 6774:2008 mengenai Tata Cara Perencanaan Unit Paket Pengolahan Air $^{[5]}$. Pengolahan yang terpilih disusun menjadi kompak seperti yang terlihat pada layout di bawah ini.

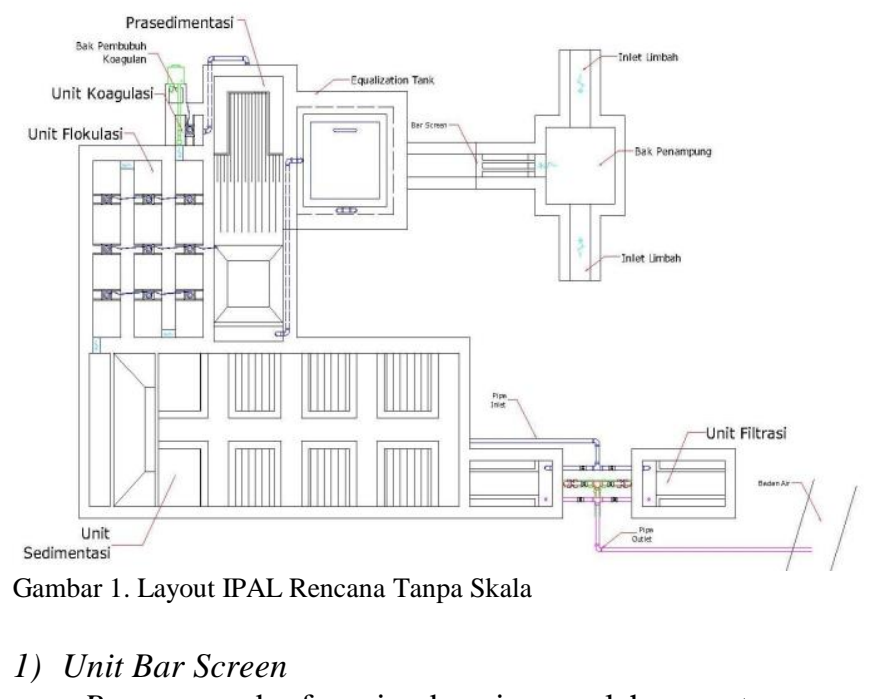

Bar screen berfungsi sebagai pengolahan pertama yang bertujuan untuk memisahkan zat pengotor yang berukuran besar agar tidak ikut terbawa pada pengolahan selanjutnya. Berikut hasil perhitungan dari bar screen dengan pembersihan manual :

- Dimensi Bar Screen

Tabel 3.

Dimensi Bar Screen

\begin{tabular}{lc}
\hline \hline \multicolumn{1}{c}{ Komponen } & Satuan \\
\hline Lebar screen & $0.1 \mathrm{~m}$ \\
sudut kemiringan screen & 45 \\
Bentuk bar & Bulat \\
jarak antar batang (b) & $0.025 \mathrm{~m}$ \\
kecepatan melalui celah & $0,3-0,6 \mathrm{~m}^{2} / \mathrm{s}$ \\
lebar bar (w) & $0.005 \mathrm{~m}$ \\
kedalaman bar & $0.1 \mathrm{~m}$ \\
faktor bentuk ( $\beta$ ) & 1.79 \\
Jumlah bar (n) & 2 \\
Jumlah bukaan antar bar (s) & 3 \\
lebar bukaan antar bar total (Lt) & $0.075 \mathrm{~m}$ \\
panjang kisi terendam air & $0.1 \mathrm{~m}$ \\
Koefisien efisiensi (n) & $87 \%$ \\
Vs saat bersih & $0.24 \mathrm{~m}^{2} / \mathrm{s}$ \\
\hline \hline (sumber : hasil perhitungan) &
\end{tabular}




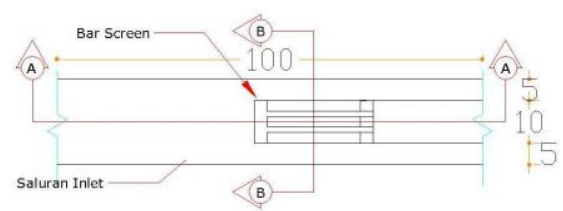

Gambar 2. Denah Bar Screen Tanpa Skala

\section{2) Unit Bak Ekualisasi}

Bak Ekualisasi berfungsi sebagai penampung air limbah sebelum menuju unit pengolahan sehingga air limbah memiliki karakteristik yang homogen dan debit yang stabil.

- Direncanakan :

Jumlah bak ekualisasi

Q tiap bak

$=1 \mathrm{buah}$

$=192 \mathrm{~m}^{3} /$ hari

$=0,0022 \mathrm{~m}^{3} / \mathrm{s}$

Waktu detensi (td)

$=15$ menit $=900$ detik

Kedalaman (h)

$=1 \mathrm{~m}$

$$
=0.3 \mathrm{~m}
$$

- Dimensi Bak Ekualisasi

$\begin{array}{ll}\text { A } & =2 \mathrm{~m}^{2} \\ \text { Panjang : lebar } & =1: 1 \\ \text { Lebar } & =1,4 \mathrm{~m} \\ \text { Panjang } & =1,4 \mathrm{~m}\end{array}$

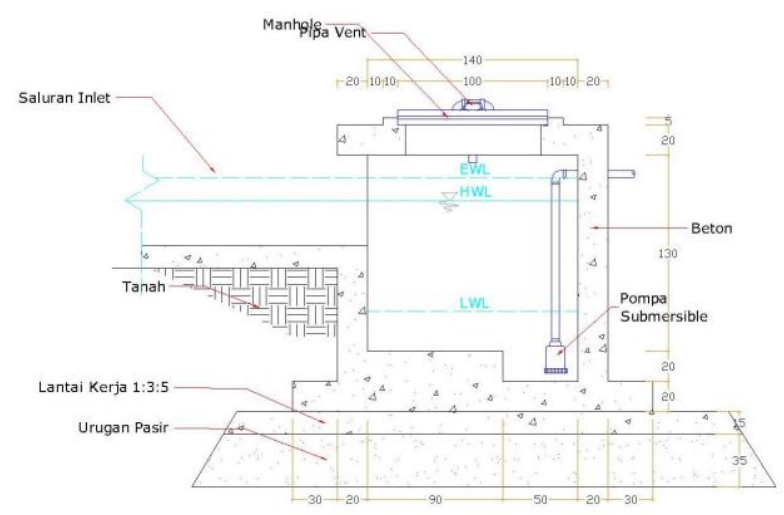

Gambar 3. Potongan Bak Ekualisasi Tanpa Skala

Untuk mengalirkan air dari bak ekualisasi menuju pengolahan selanjutnya digunakan pompa submersible dengan perhitungan diameter pipa sebesar $50 \mathrm{~mm}$. Pompa yang digunakan adalah pompa submersible.

\section{3) Unit Bak Prasedimentasi}

Pada bak prasedimentasi diharapkan mampu menyisihkan padatan-padatan yang dapat mengendap sebelum air limbah dialirkan menuju proses selanjutnya. Bangunan prasedimentasi direncanakan berbentuk Rectangular.

- Dimensi Bak Prasedimentasi

$$
\begin{array}{lll}
\text { Volume } & =6,4 \mathrm{~m} 3 \\
\text { Luas } & & =3,221 \mathrm{~m} 2 \\
\text { P:L } & =3: 1 \\
\text { Lebar } & =1,036 \mathrm{~m} \\
\text { Panjang } & =3,11 \mathrm{~m}
\end{array}
$$

Cek Bilangan Reynolds \& Bilangan Fraude

$$
\mathrm{Vh}=0,0011 \mathrm{~m} / \mathrm{s}
$$$$
\text { Vsc } \quad=0,064 \mathrm{~m} / \mathrm{s}
$$

$\mathrm{Vh}<\mathrm{Vsc}$, maka tidak terjadi penggerusan

Jari-jari hidrolis $(\mathrm{R})=0,41 \mathrm{~m}$

$$
\text { Nre } \quad=572<2000
$$

$\mathrm{Nfr} \quad=2,85 \times 10^{-7}$

- Dimensi Ruang Lumpur
Luas permukaan (A1)
$=3.2 \mathrm{~m} 2$
Luas permukaan (A2)
$=1.16 \mathrm{~m} 2$
Volume sludge selama pengurasan
Kedalaman (h)
$=1.4 \mathrm{~m} 3$
Volume ruang lumpur
$=0.6 \mathrm{~m}$

- Zona Inlet

$$
\begin{array}{ll}
\text { H rencana } & =0.5 \mathrm{~m} \\
\mathrm{~B}=\text { lebar bak } & =1 \mathrm{~m} \\
\text { Jari-jari hidrolis } & =1.5 \mathrm{~m} \\
\text { V asumsi } & =0,6 \mathrm{~m} / \mathrm{s} \\
\text { Slope } & =0,00005 \\
\text { Hf } & =0,00015 \mathrm{~m} \\
\text { Head kecepatan } & =0,018 \mathrm{~m} \\
\text { Headloss total } & =0,00015 \mathrm{~m}+0,018 \mathrm{~m} \\
& =0,01835 \mathrm{~m}
\end{array}
$$

\begin{tabular}{|c|c|c|c|c|c|c|}
\hline \multicolumn{7}{|c|}{ Uji Jartest } \\
\hline \multirow[b]{2}{*}{ Beaker Glass 1} & \multirow[b]{2}{*}{$=$} & \multicolumn{2}{|c|}{$\begin{array}{l}\text { Variasi dosis } \\
\text { PAC }\end{array}$} & \multirow{2}{*}{$\begin{array}{c}\mathrm{pH} \\
10.5\end{array}$} & \multirow{2}{*}{$\begin{array}{l}\text { NTU } \\
15.2\end{array}$} & \multirow{2}{*}{$\begin{array}{c}\text { COD } \\
(\mathrm{mg} / \mathrm{l}) \\
18000\end{array}$} \\
\hline & & 0 & $\mathrm{mg} / \mathrm{l}$ & & & \\
\hline Beaker Glass 2 & $=$ & 100 & $\mathrm{mg} / \mathrm{l}$ & 9.4 & 12.5 & 8000 \\
\hline Beaker Glass 3 & $=$ & 125 & $\mathrm{mg} / \mathrm{l}$ & 9 & 10.32 & 8000 \\
\hline Beaker Glass 4 & $=$ & 150 & $\mathrm{mg} / \mathrm{l}$ & 8.8 & 8.47 & 6000 \\
\hline Beaker Glass 5 & $=$ & 200 & $\mathrm{mg} / \mathrm{l}$ & 8.5 & 15.6 & 4800 \\
\hline
\end{tabular}

- Zona Outlet

$\begin{array}{ll}\text { H total } & =0,075 \mathrm{~m} \\ \text { Lebar pintu v notch } & =0,15 \mathrm{~m} \\ \text { Q tiap vnotch } & =0,00038 \mathrm{~m} 3 / \mathrm{s} \\ \text { Jumlah vnotch } & =6 \text { buah } \\ \text { Jumlah V notch tiap sisi } & =3 \mathrm{buah} \\ \text { Asumsi jarak tiap Vnotch } & =0,15 \mathrm{~m} \\ \text { Jarak Vn dari tepi } & =0,075 \mathrm{~m} \\ \text { Q tiap gutter } & =0,0022 \mathrm{~m} 3 / \mathrm{s} \\ \text { Panjang gutter } & =1,7 \mathrm{~m} \\ \text { Lebar gutter } & =0,004 \mathrm{~m} \\ \text { Tinggi gutter } & =0,078 \mathrm{~m} \\ \text { Tebal weir } & =0,1 \mathrm{~m}\end{array}$

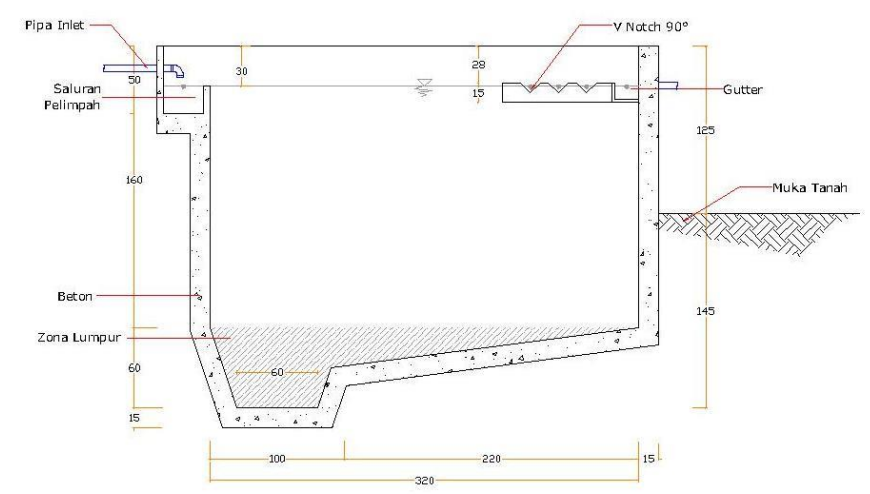

Gambar 4. Potongan Bak Prasedimentasi Tanpa Skala

4) Unit Koagulasi-Flokulasi

Koagulan yang digunakan pada bangunan koagulasi ini adalah PAC (Poly Aluminium Chloride) PAC dipilih dikarenakan mampu bekerja pada $\mathrm{pH}$ tinggi dan harga relatif murah. Uji coba jartest dilakukan terhadap sampel yang bersumber dari inlet 1 dan 2 industri agar-agar X. Didapatkan hasil sebagai berikut :

Tabel 4. Hasil Uji Jar Test 
Dari percobaan jartest tersebut didapatkan dosis optimum penambahan PAC sebesar $150 \mathrm{mg} / \mathrm{L}$ yang mampu mereduksi kadar kekeruhan paling tinggi.

Direncanakan bangunan koagulasi mekanis dengan desain sebagai berikut :

- Dimensi Bak Koagulasi:
Debit $(\mathrm{Q}) \quad=0,0022 \mathrm{~m} 3 / \mathrm{s}$
Jumlah bak $\quad=1$
Volume $\quad=0,066 \mathrm{~m} 3$
$\mathrm{H}$ rencana $\quad=0,7 \mathrm{~m}$
A surface $\quad=0,094 \mathrm{~m} 2$
Panjang : lebar $=1: 1$
Lebar $\quad=0,3 \mathrm{~m}$
Panjang $\quad=0,3 \mathrm{~m}$
Kedalaman $+\mathrm{fb}=1,2 \mathrm{~m}$
Power $\quad=0,04 \mathrm{kw}$
Efisiensi motor $=90 \%$
Ukuran impeller $=0,17 \mathrm{~m}$
Nre cek $=48126>10.000(\mathrm{OK})$
- Kebutuhan Koagulan :

$\begin{array}{llrl}\text { Kebutuhan Koagulan } & = & 28.512 & \mathrm{~kg} / \mathrm{hari} \\ \text { Volume koagulan } & = & 0.043 & \mathrm{~m}^{3} / \text { hari } \\ \text { Volume air pelarut } & = & 0.25 & \mathrm{~m}^{3} / \mathrm{hari} \\ \text { Volume larutan total } & = & 0.3 & \mathrm{~m}^{3} / \mathrm{hari}\end{array}$

- Dimensi Bak Pelarut Koagulan :

Periode pelarutan koagulan $=6$ jam sekali

Panjang: lebar $=1: 1$

Kedalaman bak $=1 \mathrm{~m}$

Volume bak $=0,05 \mathrm{~m} 3$

Luas $\quad=0,05 \mathrm{~m} 2$

Panjang $\quad=0,2 \mathrm{~m}$

Lebar $=0,2 \mathrm{~m}$

Kedalaman $+\mathrm{fb} \quad=1,3 \mathrm{~m}$

Debit koagulan $\quad=0,003 \mathrm{~L} / \mathrm{s}$

Pembubuhan menggunakan dosing pump.Selanjutnya air limbah akan masuk ke dalam bangunan flokulasi. Pada bangunan flokulasi akan terbentuk flok-flok yang lebih besar dan stabil. Perhitungan dimensi bangunan flokulasi akan dijelaskan sebagai berikut :

Tipe flokulasi yang digunakan adalah flokulasi mekanis berbentuk paddle dengan 3 kompartemen.
Luas total blade $=15 \%-25 \%$
Diameter paddle $=50 \%$ lebar bak
rotasi $=5-100 \mathrm{rpm}$

Bak terdiri dari 3 kompartemen dengan $\mathrm{G}$ masing-masing:

$\begin{array}{ll}\text { G1 } & =50 / \text { det } \\ \text { G2 } & =20 / \text { det } \\ \text { G3 } & =10 / \text { det }\end{array}$

Maka gradient rata-ratanya adalah: $\frac{50+20+10}{3}=26,67 /$ det

- Dimensi Flokulasi :

Pipa inlet flokulasi $=$ pipa outlet koagulasi

Volume bak $=\mathrm{Q} \times \mathrm{td}$

$$
=0,0022 \mathrm{~m}^{3} / \text { det } \times 1800 \text { detik }=3,96 \mathrm{~m}^{3}
$$

Tinggi $(\mathrm{H})=1$ meter + freeboard $(0,5 \mathrm{~m})$

Luas bak $(\mathrm{A})=\mathrm{V} / \mathrm{H}=3,96 / 1.5=2,64 \mathrm{~m}^{2}$

$\mathrm{P}: \mathrm{L} \quad=2: 1$

$\mathrm{A} \quad=\mathrm{P} \times \mathrm{L}$

$2,64=2 \mathrm{~L}^{2}$

$\mathrm{L} \quad=1,2 \mathrm{~m}$

$\mathrm{P}=3 \times \mathrm{L}$

$\mathrm{P}=2,3 \mathrm{~m}$

$\mathrm{H} \quad=1,5 \mathrm{~m}$
$\mathrm{L}$ tiap kompartemen $=0,4 \mathrm{~m}$

Diameter paddle $\quad=0.12 \mathrm{~m}$

Lebar paddle $\quad=0,06 \mathrm{~cm}$

Panjang paddle $\quad=0,3 \mathrm{~cm}$

Pada bak flokulasi terdiri dari 3 kompartemen, dengan kecepatan 5-100 rpm dan $\mathrm{Cd}=1,2$

Kompartemen 1

$\mathrm{G} 1=50 / \mathrm{det}$

$\mathrm{V}=1,38 \mathrm{~m}^{3}$

$\mathrm{P}=2,8$ watt

$$
\begin{aligned}
\mathrm{V} p & =\left[\frac{2 \mathrm{P}}{\operatorname{cd} \times \rho \times \mathrm{L}}\right]^{\frac{1}{3}} \\
& =\left[\frac{2 \times 2,8}{1,3 \times 995 \times(2,3 \times 0,4 \times 1)}\right]^{1 / 3}=\mathbf{0}, 17 \mathrm{~m} / \text { det }
\end{aligned}
$$

Sehingga putaran:

$$
\mathrm{n}=\frac{\mathrm{Vp}_{\mathrm{p}} 60}{\pi \times \mathrm{d} \times 0,75}=\frac{0,17 \times 60}{3,14 \times 0,12 \times 0,75}=36,09 \mathrm{rpm}
$$

Kompartemen 2

$\mathrm{G} 1=20 / \mathrm{det}$

$\mathrm{V}=1,38 \mathrm{~m}^{3}$

$\mathrm{P}=0,45$ watt

$\mathrm{Vp}=\left[\frac{2 \mathrm{p}}{\mathrm{Cd} \times \mathrm{x} \mathrm{L}}\right]^{\frac{1}{\mathrm{~s}}}$

$$
=\left[\frac{2 \times 0,45}{1,3 \times 995 \times(2,3 \times 0,4 \times 1)}\right]^{1 / 3}=0,09 \mathrm{~m} / \mathrm{det}
$$

Sehingga putaran:

$$
\mathrm{n}=\frac{\mathrm{Vpx} 60}{\pi \times \mathrm{d} \times 0,75}=\frac{0,09 \times 60}{3,14 \times 0,12 \times 0,75}=19,34 \mathrm{rpm}
$$

$\underline{\text { Kompartemen } 3}$

$\mathrm{G} 1=10 /$ det

$\mathrm{V}=1,38 \mathrm{~m}^{3}$

$\mathrm{P}=0,114$ watt

$\mathrm{Vp}=\left[\frac{2 \mathrm{p}}{\mathrm{Cd} \times p \times \mathrm{L}}\right]^{\frac{1}{g}}$

$$
=\left[\frac{2 \times 0,114}{1,3 \times 995 \times(2,3 \times 0,4 \times 1)}\right]^{1 / 3}=0,057 \mathrm{~m} / \mathrm{det}
$$

Sehingga putaran

$$
\begin{aligned}
\mathrm{n} & =\frac{\mathrm{Vp} \times 60}{\pi \times \mathrm{d} \times 0,75}=\frac{0,057 \times 60}{3,14 \times 0,12 \times 0,75}=12,1 \mathrm{rpm} \\
\mathrm{HL} & =\left(\frac{\mathrm{Q}}{0,2785 \times \mathrm{C} \times \mathrm{D}^{2,63}}\right)^{1,85} \\
& =\left(\frac{0,022}{0,2785 \times 1,3 \times(0,12)^{2,63}}\right)^{1,85}=0,00169 \mathrm{~m}
\end{aligned}
$$

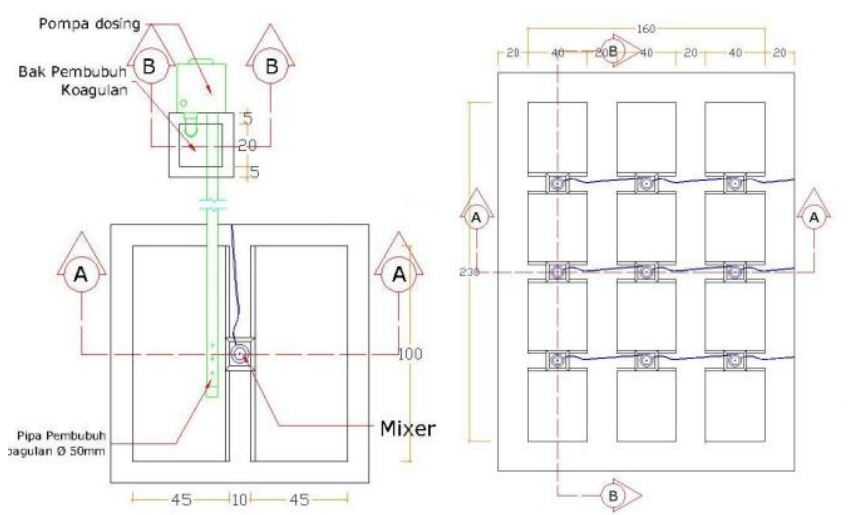

Gambar 5. Denah Unit Koagulasi - Flokulasi Tanpa Skala

5) Unit Sedimentasi

- Dimensi Bak Sedimentasi

$\begin{array}{ll}\text { Volume } & =16 \mathrm{~m} 3 \\ \text { Luas } & =8 \mathrm{~m} 2 \\ \text { Panjang : lebar }= & 3: 1 \\ \text { Lebar } & =1,6 \mathrm{~m} \\ \text { Panjang } & =4,8 \mathrm{~m}\end{array}$


- Cek Bilangan Reynolds \& Bilangan Fraude

$$
\mathrm{Vh} \quad=0,0007 \mathrm{~m} / \mathrm{s}
$$$$
\text { Vsc } \quad=0,0838 \mathrm{~m} / \mathrm{s}
$$

$\mathrm{Vh}<\mathrm{Vsc}$, maka tidak terjadi penggerusan

$$
\begin{array}{lll}
\text { Jari-jari hidrolis }(\mathrm{R}) & =0,58 \\
\mathrm{Nre} & & =511<2000 \\
\mathrm{Nfr} & & =0,8 \times 10-7
\end{array}
$$

- Perforated Baffle

$\begin{array}{lll}\text { D lubang } & =0,1 \mathrm{~m} \\ \text { Panjang baffle } & =2 \mathrm{~m} \\ \text { Tinggi baffle } & =2 \mathrm{~m} \\ \text { V asumsi } & =0,3 \mathrm{~m} / \mathrm{s} \\ \text { Luas tiap lubang } & =0,008 \mathrm{~m} 2 \\ \text { Luas baffle terendam } & =3 \mathrm{~m} 2 \\ \text { Luas total lubang } & =0,01 \mathrm{~m} 2 \\ \text { Jumlah lubang } & =2 \mathrm{buah} \\ \text { Vertikal = 1, horizontal } & =2 \\ \text { Jarak horizontal antar lubang } & =0,48 \mathrm{~m} \\ \text { Jarak vertical antar lubang } & =0,95 \mathrm{~m} \\ \text { Vh } & & =0,001 \mathrm{~m} / \mathrm{s} \\ \text { R } & & =0,025\end{array}$

- Dimensi Ruang Lumpur

$\begin{array}{ll}\text { Luas permukaan (A1) } & =8 \mathrm{~m} 2 \\ \text { Luas permukaan (A2) } & =3.92 \mathrm{~m} 2 \\ \text { Volume sludge selama pengurasan } & =1.4 \mathrm{~m} 3 \\ \text { Kedalaman (h) } & =1 \mathrm{~m} \\ \text { Volume ruang lumpur } & =5.4 \mathrm{~m} 3\end{array}$

- Zona Inlet

$\mathrm{V}$ inlet outlet $=0,9 \mathrm{~m} / \mathrm{s}$

$\mathrm{n}$ (kekasaran) $=0,015$

Jari-jari hidrolis $=2,1 \mathrm{~m}$

Slope $\quad=0,00008$

$\mathrm{Hf} \quad=0,000024 \mathrm{~m}$

Head kecepatan $=0,04895 \mathrm{~m}$

Headloss total $=0,00002 \mathrm{~m}+0,04895 \mathrm{~m}$

$$
=0,04897 \mathrm{~m}
$$

- Zona Outlet

Jumlah gutter

Q tiap gutter

$=8$ buah

$=0,0022 \mathrm{~m} 3 / \mathrm{s}$

Panjang gutter

$=0,3 \mathrm{~m}$

Lebar gutter

$=0,5 \mathrm{~m}$

Tinggi gutter

$=0,6 \mathrm{~m}$

Tebal weir

$$
=0,1 \mathrm{~m}
$$

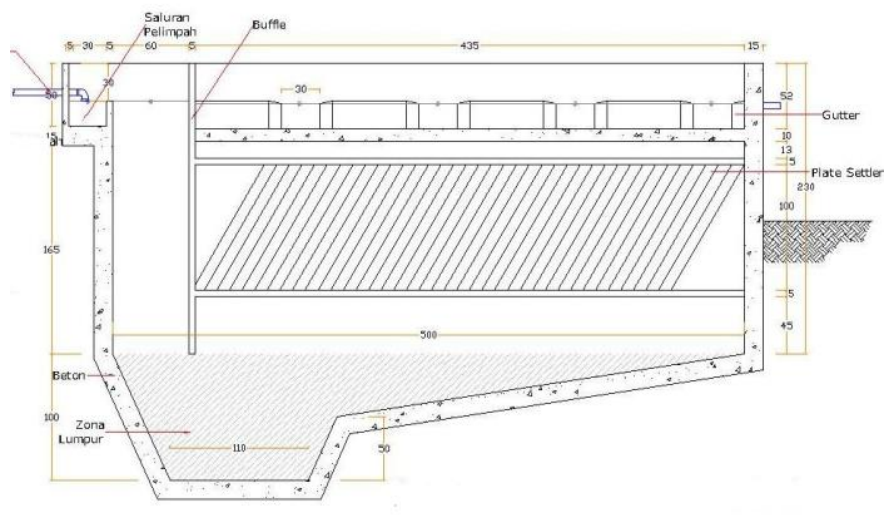

Gambar 6. Potongan Unit Sedimentasi Tanpa Skala

6) DED Filter

Bangunan filter ini dirancang menggunakan jenis filter Rapid Sand Filter single media. Media yang digunakan adalah batu zeolit. Zeolit dipilih sebagai media dikarenakan kemampuan dari zeolite untuk mereduksi kadar salinitas

\begin{tabular}{|c|c|}
\hline Jumlah bak & $=2 \mathrm{bak}$ \\
\hline Q tiap bak & $=0,0011 \mathrm{~m} 3 / \mathrm{s}$ \\
\hline Luas tiap bak & $=0,6667 \mathrm{~m} 2$ \\
\hline $\mathrm{L}$ & $=0,6 \mathrm{~m}$ \\
\hline$P$ & $=1,2 \mathrm{~m}$ \\
\hline $\mathrm{H}$ & $=3 \mathrm{~m}$ \\
\hline
\end{tabular}
pada air. Adapun efisiensi removal zeolit menurut Darmawansa(2014) ${ }^{[1]}$ sebesar $27,31 \%$ dalam menurunkan salinitas. Perhitungan bangunan filter dapat dijelaskan sebagai berikut :

- Dimensi Bak:

- Perhitungan Dimensi Underdrain

Luas bukaan orifice $(\mathrm{Ao})=$

Jumlah lubang orifice tiap bak $=13$ lubang

Luas bukaan lateral (A lat) $\quad=0.003 \quad \mathrm{~m}^{2}$

Luas total manifold (A man) $\quad=0.01 \quad \mathrm{~m}^{2}$

Diameter manifold (Dman) $\quad=0.080 \quad \mathrm{~m}$

panjang manifold $\quad=1.2 \quad \mathrm{~m}$

Jumlah pipa lateral $\quad=10 \quad$ buah

jumlah lateral tiap sisi $\quad=5 \quad$ buah

Panjang pipa lateral tiap sisi $\quad=0.270 \quad \mathrm{~m}$

Diameter lateral (Dlat) $\quad=0.0206 \quad \mathrm{~m}$

$\begin{array}{lll}\text { Jumlah orifice tiap lateral } & =2 & 2\end{array}$

- Cek Bilangan Reynolds

Cek Nre

Coefisient Drag $(\mathrm{Cd})$

Headloss

$=2.65<5$

- Backwash

$\mathrm{V}$ bw

$$
=6 \mathrm{x} \mathrm{Vf}
$$

$=0.01 \mathrm{~m}^{2} / \mathrm{s}$

Porositas saat ekspansi

(Pe)

$=0.71$

$\%$ ekspansi

$=140 \%$

Le zeolit (Tinggi

Ekspansi)

Le kerikil

$=\quad 11.2$

$=\quad 0.20 \mathrm{~m}$

$\mathrm{Pe}$

Q bw

volume bw

$=1.6$

$=0.23$

$=0.7$

$=\mathrm{V}$ bw x A bak

$=0.01 \mathrm{~m}^{3} / \mathrm{s}$

$=4 \mathrm{~m}^{3}$

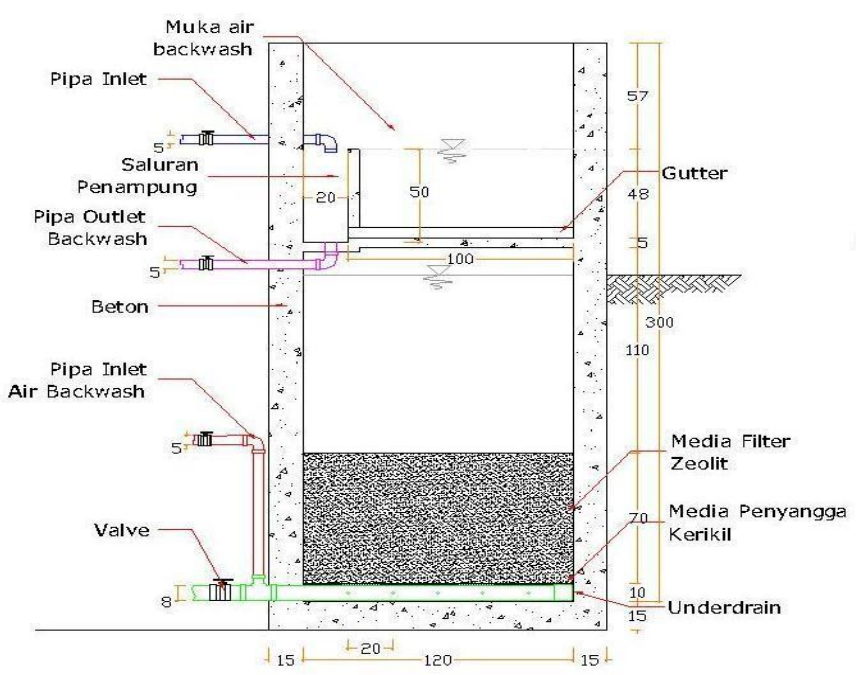

Gambar 7. Potongan Unit Filter Tanpa Skala 


\section{E. Rencana Anggaran Biaya}

Perhitungan Rencana Anggaran Biaya (RAB) didasarkan pada HSPK Kota Malang tahun 2015 dan didapatkan rekapitulasi biaya sebesar Rp141.665.444,00.

\section{KESIMPULAN DAN SARAN}

Kesimpulan pada Perencanaan IPAL (Instalasi Pengolahan Air Limbah) untuk Industri Agar-agar ini terdiri dari 3 poin, yakni :

1) Air limbah yang digunakan sebagai sampel pada perencanaan tugas akhir ini didapatkan dari outlet 1 dan 2 industri agar-agar $\mathrm{X}$ dimana hanya diambil 3 parameter yang tidak memenuhi baku mutu yakni BOD sebeasar $514,4 \mathrm{mg} / \mathrm{l}$, COD sebesar 1710,6 mg/l dan TSS sebesar $269,3 \mathrm{mg} / \mathrm{l}$. Baku mutu yang digunakan adalah PerGub Jatim no. 72 tahun 2013. Pada parameter baku mutu tidak ditemui parameter salinitas. Namun berdasarkan hasil uji laboratorium, inlet mengandung salinitas sebesar 4,4 yang harus diturunkan kadarnya sebelum dibuang ke badan air.

2) Pengolahan yang dipilih berupa pengolahan fisik kimia, karena karakteristik limbah cair yang akan diolah memiliki kadar $\mathrm{pH}$ yang tinggi dan memiliki salinitas yang melewati ambang baku mutu. Unit yang dipilih adalah bar screen, bak ekualisasi, prasedimentasi, koagulasi dan flokulasi, sedimentasi dan terakhir berupa rapid sand filter dengan media zeolit.

3) Melalui perhitungan Rencana Anggaran Biaya menggunakan HSPK Kota Malang 2015.Hasil total Rencana Anggaran Biaya adalah sebesar Rp141.665.444,00. Jumlah biaya sebesar ini merupakan jumlah yang ekonomis untuk pembangunan IPAL suatu industri.

Saran yang ingin disampaikan penulis melalui tugas akhir ini adalah :

1) Pengolahan air limbah secara fisik kimia dapat dipilih untuk diterapkan pada industri agar-agar dikarenakan karakteristik limbah cair yang dihasilkan dari pencucian agar-agar ,memiliki pH basa yang akan menyulitkan untuk diolah secara biologis

2) Pada industri agar-agar $X$, terdapat 3 jumlah outlet dimana outlet ketiga memiliki kadar pencemar yang rendah dikarenakan hanya bersumber dari proses pemasakan dan filtrasi tepung agar-agar. Outlet 3 disarankan dapat diolah menjadi air bersih untuk kepentingan produksi cukup dengan menggunakan unit pengolahan air bersih.

\section{UCAPAN TERIMA KASIH}

Perencanaan ini tidak terlepas dari keterlibatan elemen pendukung. Ucapan terima kasih ditujukan kepada Jurusan Teknik Lingkungan Fakultas Teknik Sipil dan Perencanaan Institut Teknologi Sepuluh Nopember dan Laboratorium Lingkungan Perum Jasa Tirta I atas bantuan dan dukungannya.

\section{DAFTAR PUSTAKA}

[1] Darmawansa, 2014. Desalinasi Air Payau dengan Media Adsorben Zeolit di Daerah Pesisir Pantai, Pontianak.
[2] Harga Satuan Pokok Kerja (HSPK) Kota Malang. 2015

[3] Masduqi, Ali, Assomadi A.F. 2012. Operasi dan Proses Pengolahan Air. ITS Press

[4] Peraturan Gubernur Jawa Timur no. 72 tahun 2013

[5] Sedayu, B. B., Widianto, T. N., Basmal, J., dan Utomo, B. S. B. 2007. Pemanfaatan Limbah Padat Pengolahan Rumput Laut Gracilaria sp. untuk Pembuatan Papan Partikel. Jurnal Pascapanen dan Bioteknologi Kelautan dan Perikanan. 3(1): 1-9.

[6] SNI 6774:200. Tata Cara Perencanaan Unit Paket Pengolahan Air

[7] UU RI No.32 Tahun 2009 Tentang Perlindungan dan Pengelolaan Lingkungan Hidup 